\title{
Identification of Process-Localized mRNAs from Cultured Rodent Hippocampal Neurons
}

\author{
Michael M. Poon, ${ }^{1}$ Sang-Hyun Choi, ${ }^{2}$ Christina A. M. Jamieson, ${ }^{3,4}$ Daniel H. Geschwind, ${ }^{2,3,5}$ and Kelsey C. Martin ${ }^{5,6}$ \\ ${ }^{1}$ Interdepartmental Program in Neuroscience, ${ }^{2}$ Program in Neurogenetics, Department of Neurology, ${ }^{3}$ Department of Human Genetics, ${ }^{4}$ Department of \\ Urology, ${ }^{5}$ Semel Institute for Neuroscience and Human Behavior, Department of Psychiatry and Biobehavioral Sciences, and ${ }^{6}$ Department of Biological \\ Chemistry, David Geffen School of Medicine, University of California, Los Angeles, Los Angeles, California 90095
}

\begin{abstract}
The regulated translation of localized mRNAs in neurons provides a mechanism for spatially restricting gene expression in a synapsespecific manner. To identify the population of mRNAs present in distal neuronal processes of rodent hippocampal neurons, we grew neurons on polycarbonate filters etched with $3 \mu \mathrm{m}$ pores. Although the neuronal cell bodies remained on the top surface of the filters, dendrites, axons, and glial processes penetrated through the pores to grow along the bottom surface of the membrane where they could be mechanically separated from cell bodies. Quantitative PCR and immunochemical analyses of the process preparation revealed that it was remarkably free of somatic contamination. Microarray analysis of RNA isolated from the processes identified over 100 potentially localized mRNAs. In situ hybridization studies of 19 of these transcripts confirmed that all 19 were present in dendrites, validating the utility of this approach for identifying dendritically localized transcripts. Many of the identified mRNAs encoded components of the translational machinery and several were associated with the RNA-binding protein Staufen. These findings indicate that there is a rich repertoire of mRNAs whose translation can be locally regulated and support the emerging idea that local protein synthesis serves to boost the translational capacity of synapses.
\end{abstract}

Key words: synaptic plasticity; microarray; hippocampus; protein synthesis; mRNA localization; in situ hybridization; dendrite

\section{Introduction}

The targeting of specific mRNAs to distinct subcellular regions provides an important means of regulating gene expression in neurons. Stimulus-induced translational control of localized mRNAs allows neurons to alter the protein composition of specific synapses with great temporal and spatial resolution (for review, see Steward and Schuman, 2001; Klann and Dever, 2004; Martin, 2004; Wang and Tiedge, 2004; Martin and Zukin, 2006; Schuman et al., 2006). Previous studies have described a role for local translation during axon guidance and learning-related synaptic plasticity (Martin, 2004). We and others (Miyashiro et al., 1994; Tian et al., 1999; Eberwine et al., 2001, 2002; Moccia et al., 2003; Sung et al., 2004) have been interested in identifying the population of localized mRNAs, because these are likely to encode proteins that function to produce local changes in synaptic efficacy and structure.

\footnotetext{
Received April 7, 2006; revised Nov. 14, 2006; accepted Nov. 15, 2006.

This work was supported by National Institutes of Health Grants R01MH64547 (D.H.G.) and R01NS45324 (K.C.M.) and by grants from the Waverly Smith Fund (D.H.G.) and the W. M. Keck Foundation (K.C.M.). We thank members of the Martin laboratory for useful discussion, Ivo Dinov and Dushyanth Krishnamurthy for help with the mixture distribution modeler, and Kwok On Lai for help with Q-PCR. We also thank Jim Boulter, Tom O'Dell, and Doug Black for useful advice and comments.

Correspondence should be addressed to Kelsey C. Martin, Gonda 3506/Brain Research Institute, University of California, Los Angeles, 695 Charles Young Drive, South Los Angeles, CA 90095-1761. E-mail: kcmartin@ mednet.ucla.edu.

S.-H. Choi's present address: Department of Pharmacology, Korea University College of Medicine, Seoul 136-705, South Korea.

D0I:10.1523/JNEUROSCI.3432-06.2006

Copyright $\odot 2006$ Society for Neuroscience 0270-6474/06/2613390-11\$15.00/0
}

Dendritically localized mRNAs were initially identified fortuitously in the course of in situ hybridization (ISH) analyses. More recently, unbiased approaches to amplify mRNAs from mechanically or biochemically purified dendritic and/or synaptic compartments (Miyashiro et al., 1994; Tian et al., 1999; Eberwine et al., 2002; Moccia et al., 2003; Sung et al., 2004; Zhong et al., 2006) have generated lists of localized mRNAs numbering in the hundreds (Eberwine et al., 2002). These experiments suggest that there is a large population of dendritically localized mRNAs, although wide acceptance of the dendritic localization of these mRNAs has been delayed by the lack of in situ hybridization to demonstrate that the mRNAs are indeed present in dendrites.

One of the challenges in identifying dendritically localized transcripts is that the concentration of mRNA in dendrites is orders of magnitude less than that present in cell bodies, making cell body contamination a potentially overwhelming problem. Because biochemical fractionation into synaptosomes enriches for but does not purify synaptic terminals, we chose to use a mechanical approach to separate synaptic compartments from cell bodies. Modifying a method originally described by Torre and Steward (1992), we grew dissociated hippocampal neurons on filters containing $3 \mu \mathrm{m}$ pores, through which axons and dendrites, but not cell bodies, could penetrate. We then harvested the processes and extracted RNA to use as starting material for microarray analysis.

Analysis of the microarray data indicates that over 100 mRNAs are present in the process preparation. We selected 19 of the identified mRNAs to analyze by in situ hybridization in 
cultured hippocampal neurons and found that all 19 were dendritically localized, whereas none were detected in axons. A significant fraction of the dendritically localized mRNAs encodes proteins involved in translation. In addition to confirming the dendritic localization of several transcripts by in situ hybridization, we also show that several of these mRNAs associate with the double-stranded RNA binding protein Staufen, which has been implicated in RNA localization and translational regulation (Kiebler et al., 1999; Krichevsky and Kosik, 2001; Monshausen et al., 2001; Tang et al., 2001). Together, our results validate the utility of this method of mechanically separating neuronal processes for identifying dendritically localized mRNAs.

\section{Materials and Methods}

Cell culture. Both top and bottom surfaces of $3 \mu \mathrm{m}$ pore $75 \mathrm{~mm}$ polyethylene tetraphthalate (PET) membrane filter inserts (Corning, Acton, MA) were coated with poly-D-lysine (molecular weight, $>300,000$; Sigma, St. Louis, MO) and then coated with mouse collagen IV and laminin, pH 8.5 (BD Biosciences, San Jose, CA). The second coat was aspirated, and the filter was allowed to air dry. Dissociated cells were obtained from hippocampi dissected from postnatal day 0 (P0) Sprague Dawley rats. Tissue was minced and trypsinized $(2.5 \mathrm{mg} / \mathrm{ml}$; Sigma) for $15 \mathrm{~min}$ at $37^{\circ} \mathrm{C}$. Cells were triturated and resuspended in Neurobasal-A media (Invitrogen, Grand Island, NY) containing B-27 supplement (Invitrogen), cytosine arabinoside (Sigma), Glutamax (Invitrogen), and $\beta$-mercaptoethanol (Fisher Scientific, Pittsburgh, PA). Cells were allowed to grow for $14 \mathrm{~d}$ before harvesting.

Immunocytochemistry. Cells grown on filter inserts were fixed in $4 \%$ paraformaldehyde for $15 \mathrm{~min}$. The top surface was scraped using a cell scraper, and the bottom surface (process side) was stained using the appropriate antibodies. Cells were permeabilized with $0.1 \%$ Triton X-100 for $5 \mathrm{~min}$, and free aldehydes were quenched with $50 \mathrm{~mm}$ ammonium chloride for $15 \mathrm{~min}$. Cells were then blocked with $10 \%$ normal goat serum for $1 \mathrm{~h}$. Primary antibody was added for $2 \mathrm{~h}$ [microtubuleassociated protein 2 (MAP2), mouse monoclonal, 1:1000 (Sigma); Tau, rabbit polyclonal, 1:1000 (Chemicon, Temecula, CA); GFAP, rabbit polyclonal, 1:1000 (Sigma)]. Primary antibody was rinsed off and Cy2goat $\alpha$ mouse and Cy3-goat $\alpha$ rabbit secondary antibodies (Invitrogen, Eugene, OR), both at 1:1000, were added for $1 \mathrm{~h}$. Filters were excised from the insert, mounted onto a microscope slide, and imaged with a Zeiss (Thornwood, NY) Pascal laser scanning microscope.

For immunoblotting, lysates were prepared by scraping the top or bottom surface using small volumes of PBS, as described below for RNA collection. Laemmli sample buffer was then added, and the samples were boiled and separated by SDS-PAGE. Process and top protein quantities were normalized using the somatodendritic marker MAP2 (mouse monoclonal; Sigma). A polyclonal pan-histone H3 antibody (Upstate Biotechnologies, Charlottesville, VA) was used at a concentration of 1:1000 and detected with an HRP rabbit IgG secondary antibody (Cell Signaling Technology, Danvers, MA) followed by ECL Plus (GE Healthcare, Piscataway, NJ).

Process collection and RNA preparation. Media were aspirated, and the cell processes were rapidly separated from their cell bodies by scraping the bottom surface with a rubber cell scraper (Fisher Scientific). Harvested processes were immediately added to Trizol (Invitrogen), and the scraper was also rinsed in Trizol. RNA was extracted according to the Trizol protocol, with the addition of linear acrylamide (Ambion, Austin, TX) to facilitate precipitation. Pelleted RNA was then dissolved in Resuspension Solution (Ambion). Reference RNA was generated from P3 rat forebrain tissue extracted with Trizol.

RNA amplification and microarray probe preparation. RNA quantity and quality were measured using a NanoDrop (Wilmington, DE) spectrophotometer and Agilent (Palo Alto, CA) Bioanalyzer 2100. Total RNA $(50 \mathrm{ng})$ from each sample was then amplified according to the SMARTPCR (BD Biosciences Clontech, Mountain View, CA). Cycling parameters were as follows: $95^{\circ} \mathrm{C}$ for $1 \mathrm{~min}$ and then cycles of $95^{\circ} \mathrm{C}$ for $5 \mathrm{~s}, 65^{\circ} \mathrm{C}$ for $5 \mathrm{~s}$, and $65^{\circ} \mathrm{C}$ for $3 \mathrm{~min}$. The maximum number of cycles before PCR plateau was determined empirically to be 17 .
Amplified cDNA was quantified and direct-labeled according to Karsten and Geschwind (2003) using Klenow fragment polymerase (Prime-It II Random Primer Labeling Kit; Stratagene, La Jolla, CA). The reference sample was labeled with Cy5 $\mathrm{dCTP}$, whereas the process and whole-cell samples were labeled with Cy3 dCTP (GE Healthcare).

The labeled cDNA was precipitated with mouse Cot-1 DNA $(1 \mu \mathrm{g} / \mu \mathrm{l}$; Invitrogen), sodium acetate $(3 \mathrm{M}, \mathrm{pH} 5.2)$, and $100 \%$ ethanol at $-20^{\circ} \mathrm{C}$ for $3 \mathrm{~h}$ and washed with ethanol. The cDNA was air dried and reconstituted in hybridization buffer containing $3.5 \times$ SSC, $0.1 \%$ SDS, $2.5 \times$ Denhardt's solution, and $50 \%$ formamide. Suspensions of either the process and reference probes or of the whole cell and reference probes were denatured at $95^{\circ} \mathrm{C}$. The denatured probe suspension was preincubated at $42^{\circ} \mathrm{C}$ for $30 \mathrm{~min}$ and then applied to Mouse Microarray ConsortiumPrint 5 (MMC-P5) 18K mouse cDNA arrays (University of California, San Francisco, San Francisco, CA) and hybridized at $42^{\circ} \mathrm{C}$ overnight.

The hybridized microarrays were washed twice with $2 \times$ SSC and $0.1 \%$ SDS and then two additional times with $0.2 \times$ SSC. Cy3 and Cy5 fluorescent signals were detected using a GMS 418 Array Scanner (Genetic MicroSystems, Woburn, MA).

Microarray analysis. Three process and three whole-cell samples from separate RNA harvests were hybridized to the same reference sample in duplicate, with dye reversal. In total, 12 hybridizations were performed resulting in six process-to-reference and six whole cell-to-reference comparisons. ImaGene (version 2.0) was used to produce raw image data and subtract background signals below $1.5 \times$ background. Intensity values were loaded to GeneSpring (version 7.2; Redwood City, CA) software as two signals: process to reference or whole cell to reference. Signals from dye-flip replicate experiments were averaged and the data normalized by Lowess fit, resulting in $\sim 16,000$ spots analyzed per array (maximum $16,909)$.

Statistical analysis and hierarchical clustering were performed using GeneSpring software. Process to reference and whole cell to reference values were filtered by the Student's $t$ test, and genes with statistically significant differences between groups were retained. Two gene lists were used to select genes for additional analysis and confirmation: a more liberal list, using a cutoff of $p<0.01$ without correcting for false discovery (FDR) ( $n=444$ genes) and a more conservative list based on a $5 \%$ FDR $(n=143)$. Genes on the more conservative list were present in the longer list. For the liberal analysis $(p<0.01$; no false discovery correction), 82 of the 444 genes would be expected to pass the restriction by chance. For the conservative 5\% FDR analysis, 7 of 143 genes would be differentially expressed by chance.

Process to whole cell ratio $(\mathrm{P} / \mathrm{T})$ was calculated using Microsoft Excel (Seattle, WA), and genes were classified into process-upregulated (P/T $>0.926)$ and process-downregulated $(\mathrm{P} / \mathrm{T}<0.926)$. Listed genes were annotated by SOURCE (December 2005) using GenBank Accession numbers. Gene lists were loaded on the Database for Annotation, Visualization, and Integrated Discovery (DAVID) 2.1 (http://david.abcc.ncifcrf.gov/) and analyzed using the functional annotation and classification tools.

In situ hybridization/immunocytochemistry. Digoxigenin (DIG)labeled riboprobes were generated either from plasmids or PCR templates adapted with T3 and T7 RNA polymerase sites. With the exception of heterogeneous nuclear ribonucleoprotein (hnRNP) A/B [analyzed at $8 \mathrm{~d}$ in vitro (div)], all in situ hybridizations were performed on dissociated hippocampal neurons at $14 \mathrm{~d}$ in vitro. Cells were fixed with $4 \%$ paraformaldehyde, permeabilized with $0.5 \%$ Triton X-100, and incubated in DEPC PBS containing $0.1 \%$ active DEPC. Cells were then prehybridized with a buffer containing a final concentration of $50 \%$ formamide and $50 \%$ Rapid-Hyb buffer (GE Healthcare) at the temperature used for the subsequent hybridization (supplemental Table 3, available at www. jneurosci.org as supplemental material). Cells were then washed in a buffer consisting of a final concentration of $1 \times$ SSC and 50\% formamide at the temperature indicated in supplemental Table 3 (available at www. jneurosci.org as supplemental material). Under these wash conditions, the hybridization stringency (the percentage homology between the probe and target necessary for hybridization) is between 92 and $96 \%$. Cells were incubated with an HRP-linked DIG antibody (1:1000; Roche, Indianapolis, IN) and MAP2 antibody for $1 \mathrm{~h}$. Cells were then processed 
for tyramide signal amplification using a Cy3-TSA kit (PerkinElmer, Wellesley, MA). MAP2 was then detected using a goat- $\alpha$-mouse antibody linked to AlexaFluor 488 (Invitrogen). Samples were imaged on a Zeiss Pascal confocal microscope, with identical settings used for sense, antisense, and RNase-treated cells.

Coimmunoprecipitation of RNAs associated with Staufen protein. Hippocampi from P14-P21 rats were dissected in DEPC PBS and then homogenized in lysis buffer containing $300 \mathrm{~mm} \mathrm{KCl}, 2 \mathrm{~mm} \mathrm{MgCl}_{2}, 20 \mathrm{~mm}$ Tris॰ $\mathrm{Cl}, \mathrm{pH}$ 7.4, 2 mм DTT, 0.05\% deoxycholate with RNAGuard (GE Healthcare) and Protease Inhibitor Cocktail (Sigma) with a Dounce homogenizer. The lysate was precleared with anti-rabbit IgG-Sepharose (eBiosciences, San Diego, CA). The supernatant was then divided into two Microfuge tubes and either $10 \mathrm{ng}$ of anti-human Staufen 1 antibody (AbCam, Cambridge MA; QVEYKDFPKNNKNEF) was added per microliter of supernatant or an equivalent volume of PBS was added to the mock control and rotated end-over-end overnight at $4^{\circ} \mathrm{C}$. Anti-rabbit IgG beads were then added to the mixture and rotated for $1 \mathrm{~h}$ at room temperature. The pellet was centrifuged at $10,000 \times g$ for $3 \mathrm{~min}$ and washed three times with lysis buffer containing RNA Guard (GE Healthcare) and Protease Inhibitor Cocktail. A small aliquot of beads was removed for protein analysis. The RNA on the remaining beads was extracted with Trizol. Immunoprecipitation of Staufen protein was verified using the eBiosciences Rabbit Trublot kit, which allows for the detection of native but not denatured antibody. The aliquot reserved for protein analysis was denatured in protein sample loading buffer as described in the product protocol. The protein was run on an SDS-PAGE gel and transferred to a polyvinylidene difluoride membrane. The blot was incubated with Staufen antibody at 1:1000 and detected with an HRP-rabbit IgG secondary antibody (Cell Signaling Technology, Danvers, MA) and ECL Plus (GE Healthcare). RNA was quantified using a Nanospec, and equivalent amounts of total RNA were oligodT primed and reverse transcribed with Superscript III (Invitrogen, Carlsbad, CA). PCR primers amplifying $200 \mathrm{bp}$ products were designed using PCR Now (http:// pathogene.swmed.edu/rt_primer/). Quantitative PCR (Quantitect SYBR Green Kit; Qiagen, Germantown, MD) was used to determine cycle thresholds for the various transcripts and standard PCR using Hotstart Taq polymerase (Qiagen) SYBR Green (Invitrogen, Eugene, OR) was then performed to confirm and better visualize the fold change. Quantitative PCR was performed on equal amounts of process and whole-cell RNA reverse transcribed with Superscript II (Invitrogen, Carlsbad, CA).

Colocalization of Staufen-enhanced green fluorescent protein with $m R N A$. Full-length rat Staufen 1 was cloned using primers containing Eco RI and Bam HI adaptor sequences for ligation into the enhanced green fluorescent protein (EGFP)-N1 vector (Clontech). PCR was performed using Easy-A modified Pfu polymerase (Stratagene). Sticky ends were generated by digesting the vector and PCR product with the appropriate restriction enzymes. Ligation was performed using Quick Ligase (New England Biolabs, Ipswich, MA) and verified by sequencing.

Primary hippocampal neurons were transfected with the StaufenEGFP construct or EGFP vector alone at $7 \mathrm{~d}$ in vitro using Lipofectamine 2000 (Invitrogen, Carlsbad, CA). The construct was allowed to express for $18 \mathrm{~h}$ before fixation. In situ hybridization was performed as described above except that a mouse EGFP antibody (1:500; Clontech) was used rather than MAP2 antibody to enhance detection of the EGFP signal.

\section{Results}

\section{Mechanical purification of processes from cultured} hippocampal neurons

We used a mechanical approach to separate neuronal cell bodies from their processes, modifying a method originally devised by Torre and Steward (1992). Dissociated hippocampal neurons were plated onto PET membranes etched with $3 \mu \mathrm{m}$ pores and coated on top and bottom surfaces with collagen IV and laminin and allowed to grow for $14 \mathrm{~d}$. At this time, axons, dendrites, and glial processes had grown through the pores and extended along the bottom surface of the filter. Neuronal and glial cell bodies, which are too large to penetrate through the pores, remained on
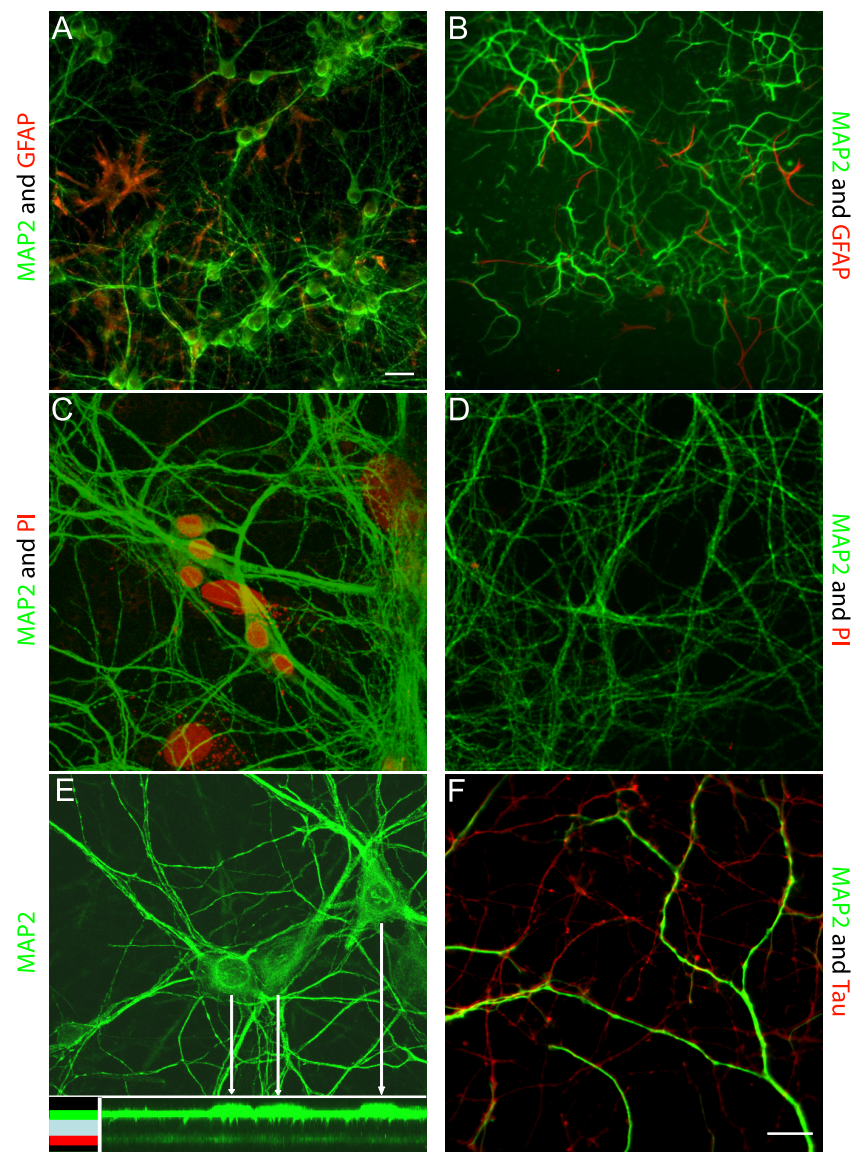

G
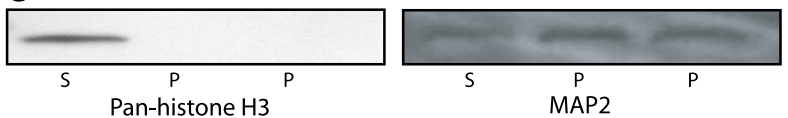

Figure 1. Mechanical separation of neuronal processes from cell bodies. Dissociated hippocampal neurons were grown on filter membranes etched with $3 \mu \mathrm{m}$ pores and imaged at $14 \mathrm{~d}$ in vitro. Removal of cells from the top surface with a cell scraper revealed that a pure preparation of dendrites, axons, and glial processes was present on the bottom surface. $\boldsymbol{A}$, The cultures consisted of MAP2-immunopositive neurons (green) and GFAP-immunopositive astrocytes. $\boldsymbol{B}$, When the top surface of the filter was removed with a cell scraper, MAP2immunopositive dendrites and some GFAP-immunopositive glial processes remained on the bottom surface. $\boldsymbol{F}$, After removal of the top surface, the bottom surface also contained tauimmunopositive axons (red) in addition to MAP2-immunopositive dendrites (green). Staining of intact filters with propidium iodide (PI) for nuclei (red) and MAP2 for neuronal somata and dendrites (green) in intact filters $(\boldsymbol{C})$ and in filters after removal of the top surface $(\boldsymbol{D})$ revealed that the bottom surface was devoid of nuclei. $\boldsymbol{E}$, MAP2-stained cultures were imaged by confocal microscopy $(\boldsymbol{E})$, and the reconstructed image was visualized in the z-plane ( $\boldsymbol{E}$, inset), showing that cell bodies (white vertical arrows) were restricted to the top of the filter (bottom left inset, green bar), and that MAP2-immunopositive dendrites penetrated through the $10-\mu \mathrm{m}$ thick filter (bottom left inset, light blue bar) to grow along the bottom surface of the filter (bottom left inset, red bar). G, Immunoblot analysis of the top (cell soma, S) and bottom (process, $P$ ) preparations revealed that the bottom lacked histone $H 3$, a nuclear marker. Scale bars: (in $\boldsymbol{A}) \boldsymbol{A}-\boldsymbol{E}, 10 \mu \mathrm{m} ; \boldsymbol{F}, 10 \mu \mathrm{m}$.

the top surface of the filters. To separate neuronal processes from cell bodies, we scraped the bottom surface with a cell scraper.

As shown in Figure 1, cultures grown on filters contained MAP2 and Tau-immunoreactive neurons and GFAPimmunoreactive astrocytes. No OP-1 immunoreactive oligodendrocyte processes were detected (data not shown). MAP2immunoreactive dendrites penetrated from the top surface through the pores to grow along the bottom surface of the filters (Fig. 1B,E). Quantification of optical sections obtained by con- 


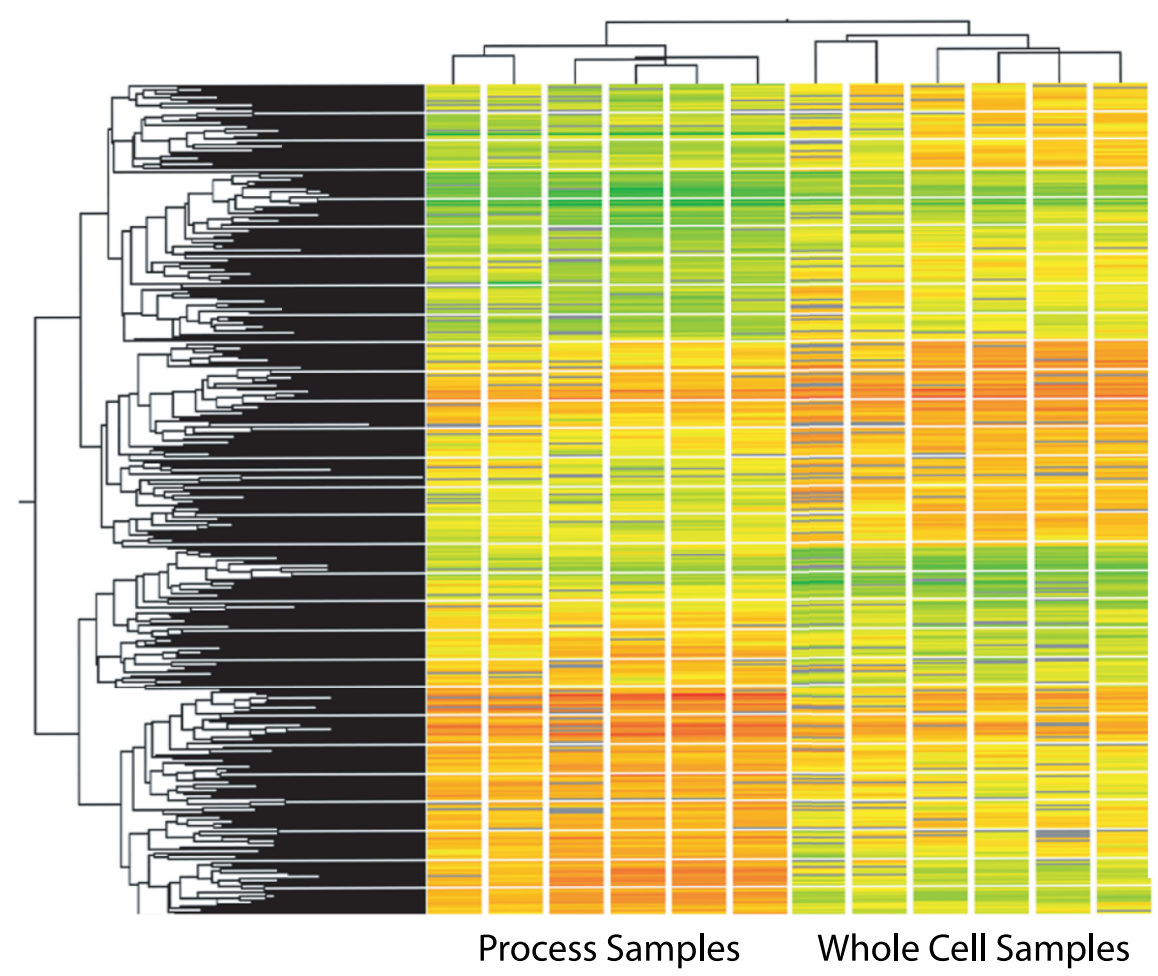

$\begin{array}{llllllllllll}1-1 & 1-2 & 2-1 & 2-2 & 3-1 & 3-2 & 1-1 & 1-2 & 2-1 & 2-2 & 3-1 & 3-2\end{array}$

Figure 2. Unsupervised hierarchical clustering of gene expression demonstrates reproducibility and reveals distinct patterns of gene expression between the arrays hybridized with either whole-cell sample or sample from cell processes. Transcripts that were analyzed were from the $p<0.01$ without FDR. Similar results were also obtained using $p<0.05$ with FDR threshold. Array hybridizations are designated $X-Y$, where $X$ denotes which harvest the RNA was collected from and $Y$ denotes the replicate number.

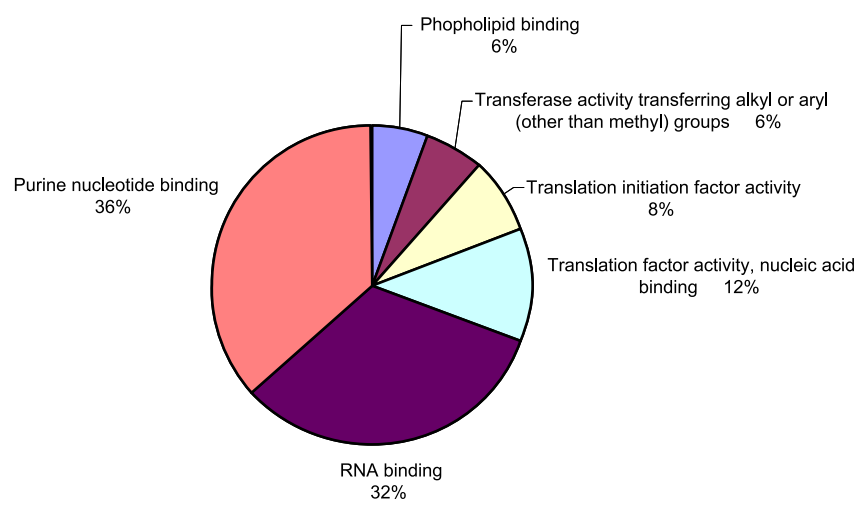

Figure 3. Functional categories present in the process mRNA sample.

focal microscopy revealed that $\sim 19 \pm 2.8 \%$ of all MAP2-positive processes were present on the bottom surface of the filter. To visualize the efficacy of our mechanical separation, we scraped the top surface of the filter with a cell scraper and then fixed and stained the filters with anti-MAP2, Tau, and GFAP antibodies. The majority of processes on the bottom surface were neuronal, consisting of both MAP2 immunoreactive dendrites and Taupositive axons (Fig. $1 B, F$ ), with a minority of GFAP-positive astrocytic processes (Fig. $1 B$ ). No nuclei were present on the bottom surface, as assessed by propidium iodide staining (Fig. $1 C, D)$. Further confirming the lack of somatic contamination in the process preparation, immunoblot analysis revealed that the nuclear protein histone $\mathrm{H} 3$ was present in the top preparation but absent from the bottom preparation (Fig. 1G).
We analyzed the quality and quantity of the RNA harvested from the bottom surface using an Agilent 2100 Bioanalyzer and Nanodrop spectrophotometer, respectively. A $75 \mathrm{~mm}$ filter plated at $\sim 8$ million cells yielded an average of $20 \mu \mathrm{g}$ of total RNA when both top and bottom surfaces were collected and an average of $150 \mathrm{ng}$ of total RNA when only the bottom surface was collected. Thus, the process preparation contained $\sim 0.75 \%$ of all the RNA collected. Together with the finding that $19 \pm$ $2.8 \%$ of dendrites were present on the bottom surface of the filter, one can use these numbers to approximately estimate that $3.9 \%$ of total cellular RNA is present in dendrites. This may be a slight overestimate, because RNA is present in glial processes (Medrano and Steward, 2001) and may also be present in axons (Giuditta et al., 2002). However, it is to our knowledge the first estimation of the relative quantity of RNA in dendrites. Because the Agilent Bioanalyzer determines the quality of an RNA sample based on 18 S and 28 S rRNA amounts, we could also use this information to gain insight into the relative quantities of rRNA in the process compared with the whole cell. Approximately $0.45 \%$ of rRNA was present in the process preparation. Given that $19 \pm 2.8 \%$ of dendrites penetrated to the bottom surface of the filter, one can estimate that $\sim 2.4 \%$ of rRNA is present in dendrites. The data also indicated that the ratio of $18 \mathrm{~S}$ to $28 \mathrm{~S}$ rRNA in neuronal processes was the same as in the cell body.

To further assess the purity of our preparation, we conducted quantitative PCR experiments comparing a somatically restricted transcript with a number of dendritically localized transcripts, using equal amounts of total RNA as starting material $(n=3$ per transcript). A somatically restricted transcript, SM51, small nuclear ribonucleoprotein N (Buettner et al., 2000) was $>10$-fold decreased in the process preparation compared with the wholecell preparation. Glyceraldehyde-3-phosphate dehydrogenase (GAPDH), another somatically restricted transcript, was also significantly ( $>1.5$-fold) enriched in the whole-cell preparation compared with the process preparation (Litman et al., 1994). In contrast, calcium calmodulin-dependent protein kinase II $\alpha$ (CaMKII $\alpha$ ) mRNA, which is known to be dendritically localized (Burgin et al., 1990), was enriched 1.5-fold in the process preparation. Several other mRNAs that have been shown to be dendritically localized were also enriched in the process preparation, including elongation factor (EF) $1 \alpha(\mathrm{EF} 1 \alpha)$ (Huang et al., 2005; Tsokas et al., 2005), which was 2.6-fold enriched; Arc (Link et al., 1995; Lyford et al., 1995), 2.2-fold enriched; BDNF (Tongiorgi et al., 1997), 3.1-fold enriched; MAP2 (Garner and Matus, 1988), 4.1-fold enriched; GluR1 (glutamate receptor 1) (Ju et al., 2004; Grooms et al., 2006), 3.2-fold enriched; and Fragile X mental retardation protein (FMRP) (Weiler et al., 1997), 3.2-fold enriched. Given that all dendritically localized transcripts are also present at high concentrations in the soma and that only $19 \%$ of dendrites penetrated through the pores, these levels of enrichment, ranging from a 1.5 -fold enrichment for CaMKII $\alpha$ mRNA 
to a 4.1-fold enrichment for MAP2 mRNA, are remarkable and indicate that the process preparation was indeed strongly enriched for dendritically localized mRNAs.

\section{Microarray analysis}

The small quantities of mRNA present in dendrites necessitated an amplification step to generate sufficient quantities of probes for microarray analysis. To this end, we used SMART-PCR, which, when used before reaching the plateau phase, maintains accurate representation of transcript abundance (Puskas et al., 2002). We ensured that our experiments were performed within the linear range of amplification by first performing PCR in three cycle increments for each RNA collection (data not shown). All amplifications from both samples resulted in product sizes ranging from 0.2 to $3 \mathrm{~kb}$. The SMART-PCR amplified samples were then Klenow-labeled with Cy3 dCTP. A common reference sample (prepared from P3 rat forebrain) was also amplified and labeled with Cy5 dCTP, enabling comparisons to future experiments (Novoradovskaya et al., 2004). Both probes were then hybridized to MMC-P5 cDNA microarrays containing 18,000 genes, the bulk of which were from the National Institute on Aging 15K array set (Tanaka et al., 2000).

An unsupervised hierarchical clustering algorithm (GeneSpring) was used to determine the reproducibility of RNA harvesting, cDNA amplification, and array hybridization (Fig. 2). Clustering revealed the presence of two distinct array cluster patterns, corresponding to the process and whole-cell samples, validating that the mechanical separation technique allowed us to reproducibly collect neuronal processes that contain a distinct population of mRNAs.

We next applied statistical methods to select for differentially expressed transcripts with a higher likelihood of being in neuronal processes. After normalization to the reference probe, the median array value across replicates was calculated. A process to whole-cell ratio $(\mathrm{P} / \mathrm{T})$ was obtained by subtracting the log of the mean process value by the log of the mean whole-cell value and converting back to a non-log value or as follows: $P / T=10^{(\log \text { Process }-\log \text { Whole Cell) }}$.

To set a threshold value for those differentially expressed genes that were more likely to be in the process, we binned the data by 0.05 increments according to their $\mathrm{P} / \mathrm{T}$ ratio and plotted this ratio by the frequency of occurrence (supplemental Fig. 1a, available at www.jneurosci.org as supplemental material). In this way, we observed at least two distinct $\mathrm{P} / \mathrm{T}$ populations, consistent with a distinct process and cell body population. To select genes for additional study, we applied a mixture-distribution model (http://socr.stat.ucla.edu/htmls/SOCR_Modeler.html), which estimated the intersection threshold to be at $\mathrm{P} / \mathrm{T}=0.926$ (supplemental Fig. $1 b$, available at www.jneurosci.org as supplemental material). We then classified genes with $\mathrm{P} / \mathrm{T}$ values greater than threshold as being "process upregulated," whereas those with a $\mathrm{P} / \mathrm{T}$ value $<0.926$ were classified as being "process downregulated" (supplemental Table 1, available at www.jneurosci.org as supplemental material). The latter may include mRNAs that are present in low abundance in processes.

\section{Gene ontology}

Gene ontology tools classify transcripts according to their cellular function, which provides information about the potential function of local translation in dendrites. To this end, both process upregulated and downregulated gene sets were submitted to DAVID (2.1; http://david.abcc.ncifcrf.gov/). When the genes were examined in this manner (Molecular Function, Level 3), the
Table 1. Process-localized mRNA list organized by gene ontology (molecular function, Level 3)

Purine nucleotide binding

ATPase, $\mathrm{Ca}^{2+}$ transporting, cardiac muscle, slow twitch 2

Janus kinase 1

RAB10, member RAS oncogene family

RAS, dexamethasone-induced 1

RIKEN CDNA 2610019A05 gene

Casein kinase 1, $\alpha 1$

Dedicator of cytokinesis 9

Eukaryotic translation elongation factor $1 \alpha 1$

Eukaryotic translation elongation factor 2

Eukaryotic translation initiation factor 5

Eukaryotic translation initiation factor $5 B$

Guanine nucleotide binding protein, $\alpha$ inhibiting 2

Integrin linked kinase

Mitogen-activated protein kinase 9

Mitogen-activated protein kinase kinase kinase 7

Ras-GTPase-activating protein $\mathrm{SH} 3$-domain binding protein

Regulator of telomere elongation helicase 1

Ubiquitin-activating enzyme E1, Chr X

Eukaryotic translation initiation factor 5

Eukaryotic translation initiation factor $5 \mathrm{~B}$

Guanine nucleotide binding protein, $\alpha$ inhibiting 2

Integrin-linked kinase

Mitogen-activated protein kinase 9

Mitogen-activated protein kinase kinase kinase 7

Ras-GTPase-activating protein SH3-domain binding protein

Regulator of telomere elongation helicase 1

Ubiquitin-activating enzyme E1, Chr X

RNA binding

RNA binding motif protein 16

THO complex 4

Acidic ribosomal phosphoprotein $\mathrm{PO}$

Ethanol-induced 2

Eukaryotic translation initiation factor 3 , subunit $9(\eta)$

Eukaryotic translation initiation factor $4, \gamma 2$

Heterogeneous nuclear ribonucleoprotein $\mathrm{A} / \mathrm{B}$

Heterogeneous nuclear ribonucleoprotein $A 0$

Heterogeneous nuclear ribonucleoprotein A2/B1

Nuclease sensitive element binding protein 1

Poly A binding protein, cytoplasmic 1

Quaking

Ras-GTPase-activating protein SH3-domain binding protein

Splicing factor $3 b$, subunit 1

Splicing factor, arginine/serine-rich 1 (ASF/SF2)

Translation factor activity, nucleic acid binding

Eukaryotic translation elongation factor $1 \alpha 1$

Eukaryotic translation elongation factor 2

Eukaryotic translation initiation factor 3, subunit $10(\theta)$

Eukaryotic translation initiation factor 3 , subunit $9(\eta)$

Eukaryotic translation initiation factor 4, $\gamma 2$

Eukaryotic translation initiation factor 5

Eukaryotic translation initiation factor $5 \mathrm{~B}$

Eukaryotic translation termination factor 1

Translation initiation factor activity

Eukaryotic translation initiation factor 3 , subunit $10(\theta)$

Eukaryotic translation initiation factor 3 , subunit $9(\eta)$

Eukaryotic translation initiation factor $4, \gamma 2$

Eukaryotic translation initiation factor 5

Eukaryotic translation initiation factor $5 \mathrm{~B}$

Transferase activity transferring alkyl or aryl (other than methyl) groups

Glutathione S-transferase, $\mu 1$

Glutathione S-transferase, $\mu 2$

Phospholipid binding

Annexin A6

Annexin A7 


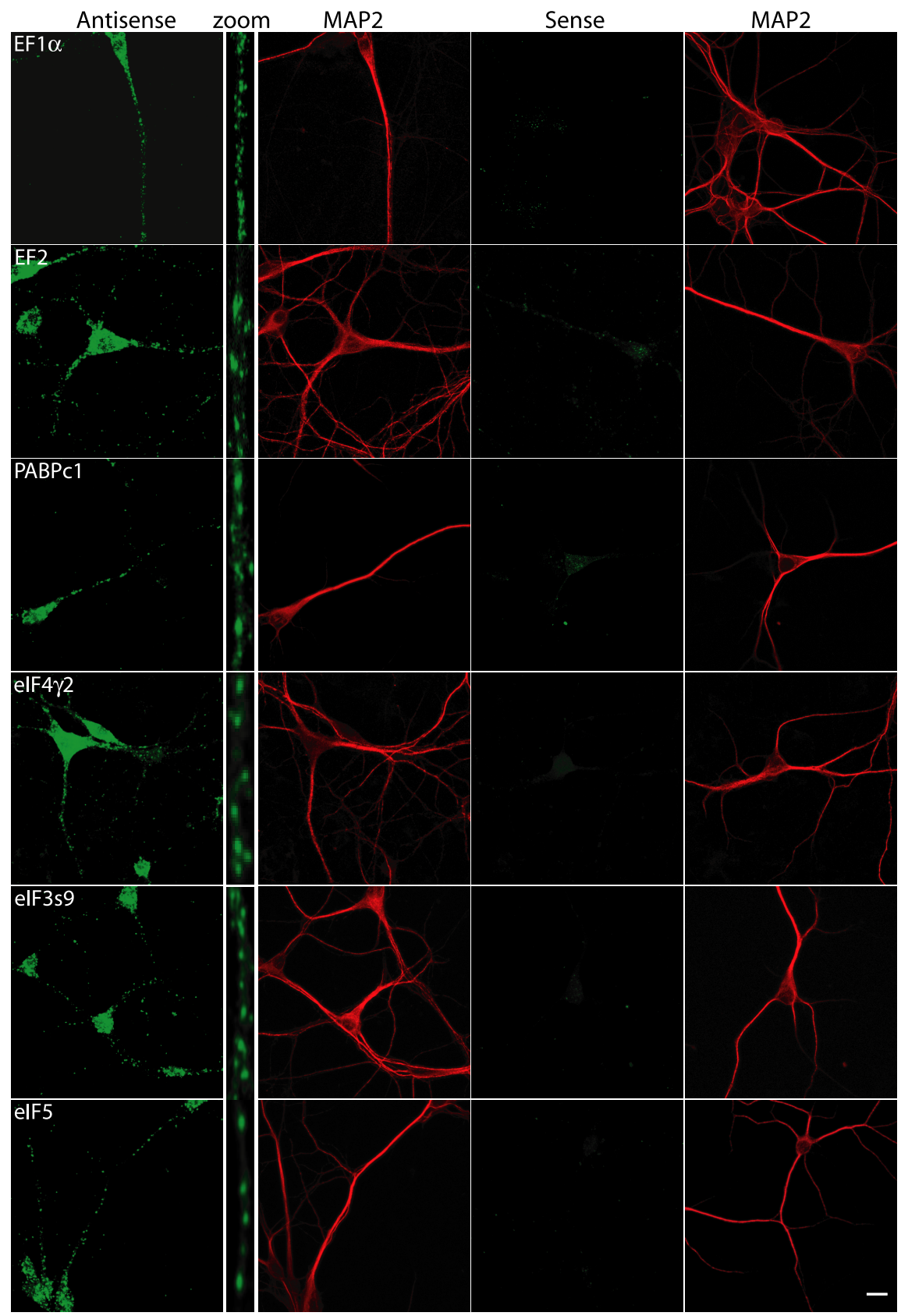

Figure 4. mRNAs encoding translation factors are present in dendrites of cultured rat hippocampal neurons (14 div) as detected by double-label ISH and MAP2 immunocytochemistry. Left to right, ISH with antisense riboprobe (green); $4 \times$ zoom of a linearized region of dendrite $>20 \mu \mathrm{m}$ from soma; double-label MAP2 immunoreactivity (red) in the antisense sample; ISH with sense control riboprobe (green); and double-label MAP2 immunoreactivity in the sense sample (red). elF $\gamma 2$, Eukaryotic initiation factor $\gamma 2$; elF3s9, eukaryotic initiation factor 3, subunit 9. Scale bar, $10 \mu \mathrm{m}$.

whole-cell sample, as expected, included genes belonging to a wide range of categories (data not shown). In contrast, genes in the process-upregulated sample contained genes belonging to a smaller subset of ontologies, most notably RNA binding and protein biosynthesis (Fig. 3, Table 1). Gene ontology analysis thus indicates that a large portion of localized mRNAs encode proteins potentially involved in the regulation of translation and supports a functional distinction between mRNAs found in processes and those in the cell body.

\section{In situ hybridization}

To confirm our microarray results, we analyzed 19 process upregulated genes by in situ hybridization of cultured hippocampal neurons. The 19 genes were selected for analysis based on their relative abundance in the process (selecting for higher P/T values), their overall abundance relative to other mRNAs (absolute signal intensity on the array), as well on the basis of gene function. As shown in supplemental Table 2 (available at www.jneurosci.org as supplemental material), 11 of the 19 genes had $\mathrm{P} / \mathrm{T}$ ratios of $>1.5$, and all 19 genes had absolute signal intensities greater than the average array value of 817 . In terms of functional interest, we concentrated on transcripts encoding proteins involved in translation (6 of the 19) and on signaling molecules with a putative role in plasticity ( 5 of the 19). To increase the sensitivity of detection, we used tyramide signal amplification (Guzowski et al., 2001). To control for specificity of the method, we performed in situ hybridization with sense riboprobes and also performed RNase pretreatment controls (supplemental Fig. $2 c$, available at www.jneurosci.org as supplemental material). In situ hybridization was performed at high stringencies, with the percentage homology between the probe and target necessary for hybridization ranging between 92 and $96 \%$. As shown in Figures 4 and 5 and supplemental Figure 2, all 19 processupregulated mRNAs were detected in dendrites by in situ hybridization. Notably, we did not detect any of the mRNAs in axons based on the absence of mRNA signal in MAP2-negative processes. In situ hybridization for $\beta$-actin was used as a positive control (Tiruchinapalli et al., 2003), whereas GAPDH was used as a negative, somatically restricted control (Fig. 5, bottom two rows).

\section{Association with RNA binding proteins and RNA granules}

The in situ hybridization analysis indicated that some mRNAs were present as puncta, suggesting localization in RNA granules (Krichevsky and Kosik, 2001). Given that the RNA binding protein Staufen has been shown to be a component of RNA granules, we performed two types of experiments to determine whether Staufen binds any of the process mRNAs and might therefore be involved in their localization. In the first set of experiments, we immunoprecipitated (IP) Staufen 1 protein from rat hippocampal lysates and used quantitative PCR with gene-specific primers to determine whether Staufen bound specific mRNAs. We focused on mRNAs that encode translation factors, including $\mathrm{EF} 1 \alpha, \mathrm{EF} 2$, eukaryotic initiation factor $4 \gamma 2$ (eIF4 $\gamma 2)$, and poly(A)-binding protein, cytoplasmic 1 (PABPc1), and found that all were enriched in the Staufen IP sample, whereas the mock immunoprecipitated sample contained little or none of the corresponding transcript (Fig. 6a). As a positive control, we tested CaMKII $\alpha$, which has been shown previously to associate with Staufen (Mallardo et al., 2003) and found that it 
was also enriched in Staufen IP sample. As a negative control, we tested histone 1 mRNA, which, as expected, did not show any enrichment in the Staufen IP. In addition, importin $\beta$, which was also identified by the array and the dendritic localization of which was confirmed by in situ hybridization, did not show enrichment in the Staufen IP sample. Together, these results indicate that Staufen may be involved in transporting mRNAs encoding translation factors into dendrites.

In a second set of experiments, we transfected primary neurons with a rat Staufen 1-EGFP construct and performed in situ hybridization for EF1 $\alpha$ or EF2 mRNA (Fig. $6 b$ ) (note that endogenous Staufen loses its antigenicity during the in situ hybridization procedure, making it impossible to do double labeling with immunocytochemistry and in situ hybridization). Staufen-EGFP was present in a punctate pattern both in the soma and in dendrites. This pattern was distinct from that of EGFP alone, which was evenly distributed throughout the cell. A fraction of Staufen-EGFP puncta colocalized with $\mathrm{EF} 1 \alpha(17.2 \pm 2 \%)$ and EF2 RNA $(12.4 \pm 4 \%)$, whereas $14.5 \pm 4 \%$ of EF1 $\alpha$ granules and $14.7 \pm 4 \%$ of EF2 granules colocalized with Staufen-EGFP. Given that the cell expresses endogenous unlabeled Staufen, these results are consistent with $\mathrm{EF} 1 \alpha$ and EF2 mRNAs being transported into dendrites in Staufen-containing granules.

\section{Discussion}

A number of studies have indicated that local translation imparts neurons with the ability to spatially restrict gene expression and to thereby alter structure and function at each of its thousands of synaptic compartments. What are the mRNAs with local translation that leads to local changes in neuronal structure and function? In this study, we undertook an unbiased identification of mRNAs present in a mechanically purified preparation of axonal, dendritic, and glial processes cultured from neonatal rat hippocampus. By mechanically separating processes from cell bodies, we were able to obtain preparations that were remarkably free from cell body contamination. The results of this analysis indicated that neuronal processes contain a rich and diverse population of mRNAs.

The small amount of RNA present in processes compared with cell bodies has plagued attempts to identify localized transcripts, because any somatic contamination inevitably overwhelms detection of process mRNAs. Separating cell bodies from processes by pores that are $3 \mu \mathrm{m}$ in diameter and $10 \mu \mathrm{m}$ in depth generated a primarily soma-free process preparation. Of the 19 transcripts identified as process-enriched by microarray analyses, all 19 were detected in dendrites by in situ hybridization. In contrast, the mRNA encoding GAPDH, which was identified as so-

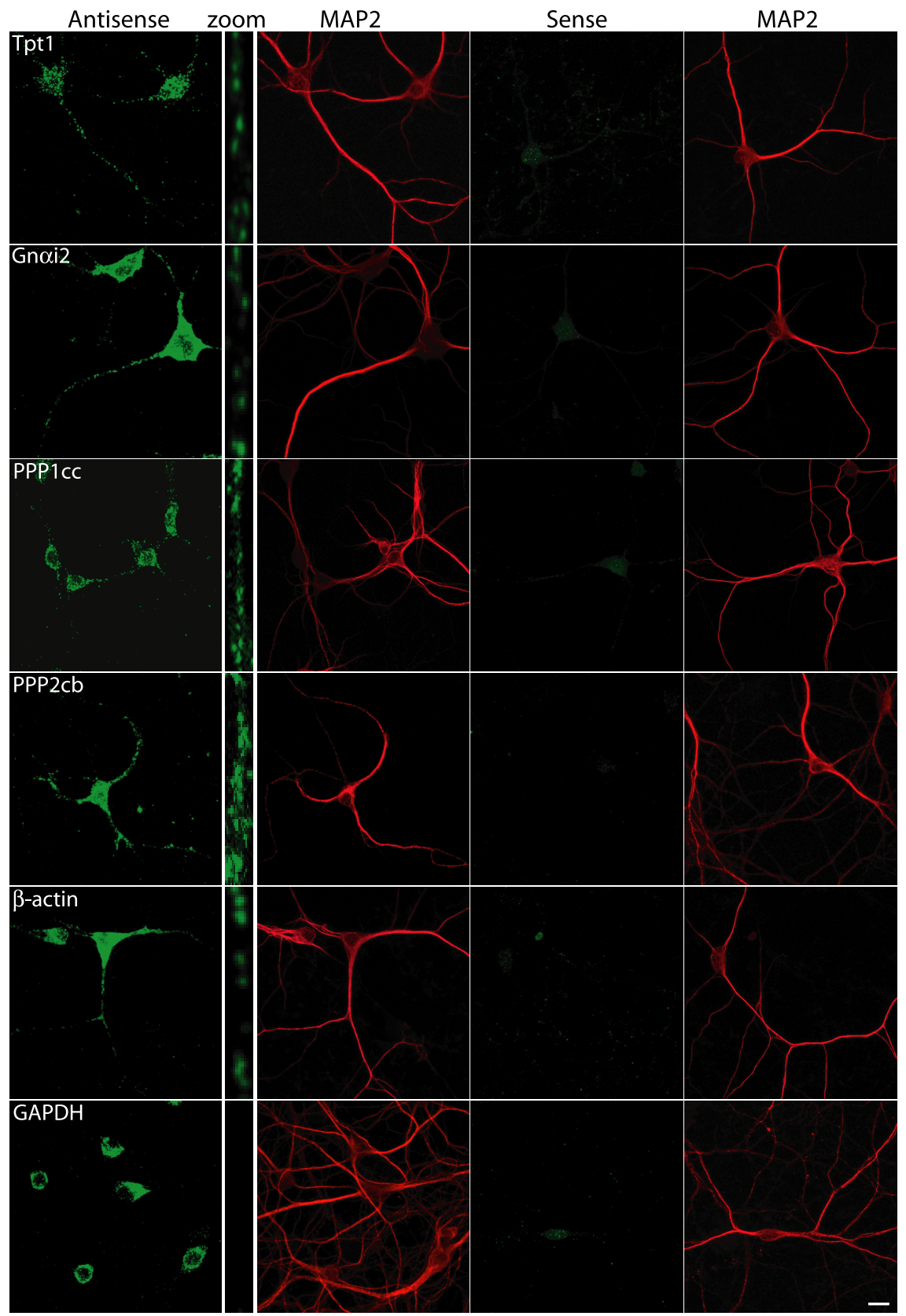

Figure 5. mRNAs encoding a variety of proteins are present in dendrites of cultured rat hippocampal neurons (14 div) as detected by double-label ISH and MAP2 immunocytochemistry. Left to right, ISH with antisense riboprobe (green); $4 \times$ zoom of a linearized region of dendrite $>20 \mu \mathrm{m}$ from soma; double-label MAP2 immunoreactivity (red) in the antisense sample; ISH with sense control riboprobe (green); and double-label MAP2 immunoreactivity in the sense sample (red). PPP1cc, Protein phosphatase 1, catalytic subunit, $\gamma$-isoform; PPP2cb, protein phosphatase 2, catalytic subunit, $\beta$-isoform. Scale bar, $10 \mu \mathrm{m}$. cell body when examined by in situ hybridization. Although our method is similar to that used by Eberwine et al. (2002) in that it depends on a mechanical separation of neuronal processes from cell bodies, it differs in that it isolates mRNAs from large populations of processes rather than from individual dendrites, thereby generating a greater amount of starting material for microarray analysis.

Local translation has been shown to occur in both dendrites and axons (Giuditta et al., 2002; Martin, 2004). Translation in axonal growth cones is required during axon guidance and synapse formation, whereas dendritic translation occurs during syn- 
A.
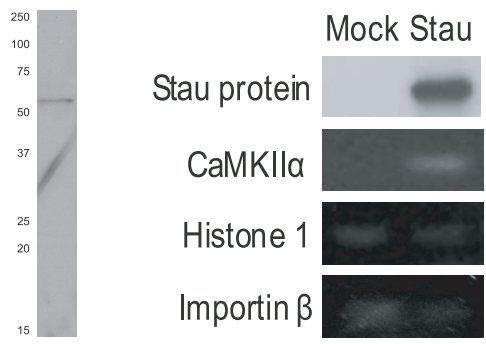

B.
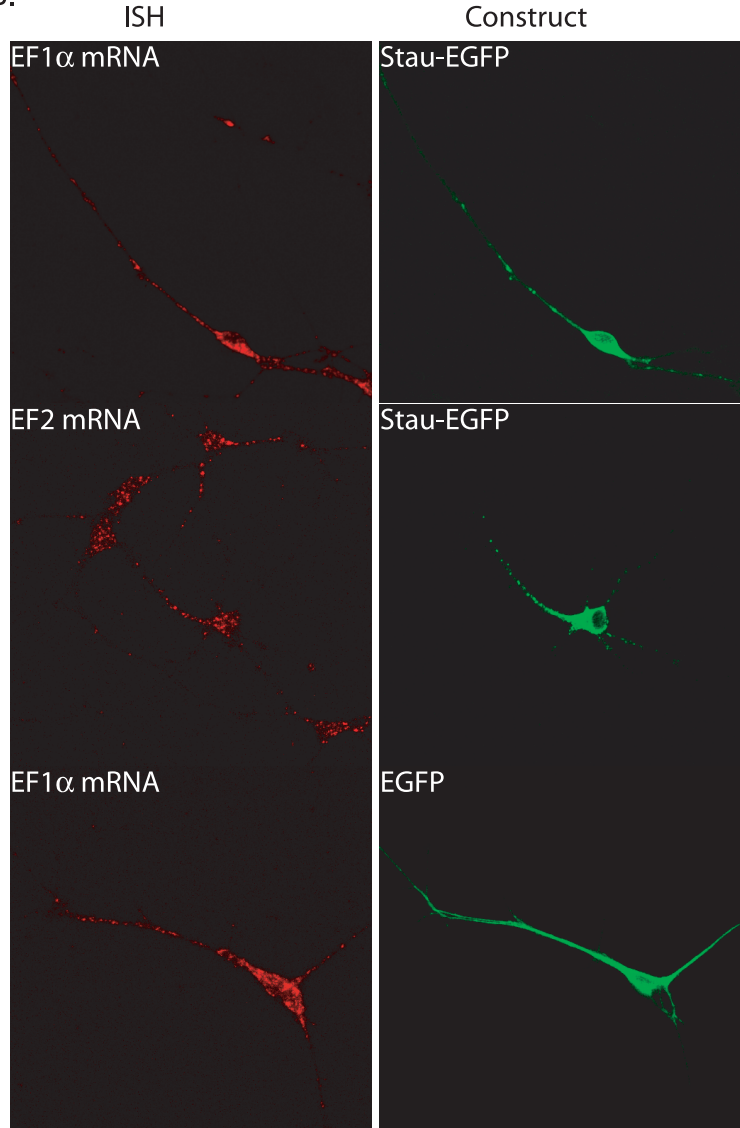
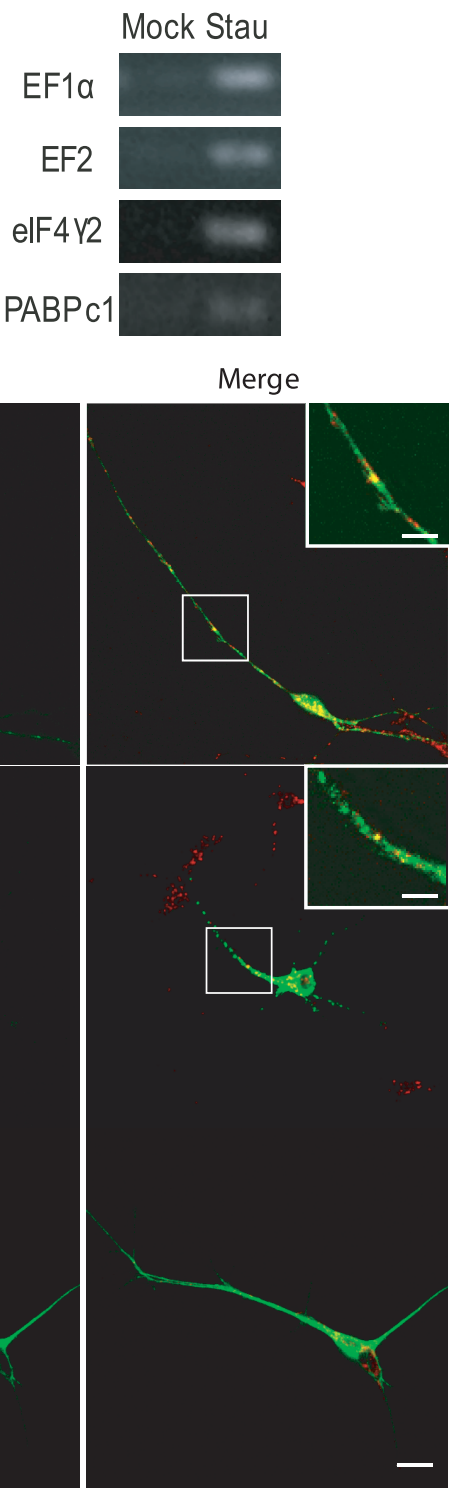

Figure 6. Staufen protein associates with dendritically localized mRNAs encoding translation factors. Hippocampal lysates were immunoprecipitated with Staufen antibody (Stau) or were incubated with anti-rabbit lgG beads in the absence of primary antibody (mock) followed by reverse transcription-PCR with gene-specific primers. $A$, Left, The immunoblot on the right shows that anti-Staufen antibody recognizes a single band of the appropriate molecular weight in hippocampal lysates. Middle, Top to bottom, Immunoblot of Staufen immunoprecipitation with anti-Staufen antibody showing that the anti-Staufen antibody immunoprecipitates Staufen protein, followed by PCR analysis of mRNAs coimmunoprecipitated with Staufen [CaMKII $\alpha$ (25 cycles), Histone 1 ( 30 cycles), and importin $\beta 1$ (32 cycles)]. Right, Top to bottom, EF1 $\alpha$ (25 cycles), EF2 (28 cycles), elF4 $\gamma 2$ ( 28 cycles), and PABPc1 (28 cycles). CaMKII $\alpha$, EF1 $\alpha, \mathrm{EF} 2$, elF4 $\gamma 2$, and PABPc1 were all enriched in the Staufen immunoprecipitates, whereas neither histone 1 nor importin $\beta 1$ were. $\boldsymbol{B}$, Transfection of dissociated hippocampal neurons (8 div) with Staufen 1-EGFP construct (Stau-EGFP) and co-ISH with either EF1 $\alpha$ (top row) or EF2 (middle row) antisense riboprobes. EF1 $\alpha$ ISH was performed with an EGFP control plasmid (bottom row). Scale bar, $10 \mu \mathrm{m}$; inset, $20 \mu \mathrm{m}$.

aptic plasticity of mature vertebrate neurons (Martin, 2004). Although axonal translation has been described in mature neurons after axonal injury (Hanz et al., 2003), whether axonal translation occurs in mature, uninjured CNS neurons remains somewhat controversial (Piper and Holt, 2004). Because our process preparation contained axons, dendrites, and glial processes, in situ hybridization analysis allowed us to determine, in an unbiased manner, whether mRNAs were preferentially localized in one or more of these distal compartments. Notably, all 19 processenriched mRNAs were present in MAP2-positive dendrites, whereas none were found in MAP2-negative axons. Although it is possible that we were unable to detect mRNAs in axons either

because they are present in such low abundance or because they are in a configuration that renders them inaccessible for probe hybridization, these data strongly suggest that the majority of local translation in hippocampal neurons grown for $14 \mathrm{~d}$ in vitro occurs in dendrites.

What insights into the function of local translation do our results provide? Perhaps the most striking finding is that a significant fraction of the localized mRNAs encodes molecules involved in translation. These molecules include translation initiation and elongation factors. We have confirmed, by in situ hybridization, the dendritic localization of mRNAs encoding three initiation factors, eIF4 $\gamma 2$, eIF3, and eIF5, and two elongation factors, $\mathrm{EF} 1 \alpha$ and EF2 (Fig. 3). By immunocytochemistry, these and other translation factor proteins have also been observed previously in dendrites (Tiedge and Brosius, 1996), and regulating the concentration of these factors has been shown to alter the dynamics of translation (Maiti and Maitra, 1997; Jivotovskaya et al., 2006). The detection of EF1 $\alpha$ mRNA in dendrites is consistent with recent studies showing that EF1 $\alpha$ is rapidly translated in stratum radiatum of hippocampal slices after stimulation (Huang et al., 2005; Tsokas et al., 2005), with previous work from our laboratory showing that EF $1 \alpha$ mRNA is present in neurites of Aplysia sensory neurons (Moccia et al., 2003) and with work from Giustetto et al. (2003) showing that EF1 $\alpha$ mRNA is transported into Aplysia sensory neuron neurites and translated after application of serotonin.

In addition to mRNAs encoding initiation and elongation factors, the mRNA encoding PABPc1, which has been shown to function to promote translation initiation (Kahvejian et al., 2005), was dendritically localized (Fig. 3). We and others previously found that the mRNA encoding the cytoplasmic polyadenylation element binding protein (CPEB) was present in neurites of Aplysia neurons, where its stimulusinduced translation is thought to generate a synaptic "tag" (Moccia et al., 2003; Si et al., 2003; Atkins et al., 2004). Together, these findings suggest that synthesis of factors that promote polyadenylation of mRNAs, such as CPEB, may serve as a general mechanism to subsequently stimulate translation of other transcripts.

The dendrite also contains several mRNAs less directly implicated in translational control than translation factors. Tpt1 (translationally controlled tumor protein 1) binds EF1 $\alpha$ in the GDP-bound configuration (Cans et al., 2003), thereby increasing translational efficiency. Visinin-like protein-1 has been shown by Mathisen et al. (1999) to bind double-stranded RNA, specifically the 3 '-untranslated region of tyrosine receptor kinase B mRNA, which is also dendritically localized, in a calcium-dependent manner (Tongiorgi et al., 1997). In Drosophila oocytes, the 
hnRNP A/B homolog, Hrp48, has been shown to bind the $5^{\prime}$ - and $3^{\prime}$-untranslated regions of oskar mRNA and repress its translation during transport (Huynh et al., 2004; Yano et al., 2004). Last, protein phosphatase $2 \mathrm{a}(\mathrm{PP} 2 \mathrm{a})$, a protein with a potential role in plasticity (Norman et al., 2000; Winder and Sweatt, 2001; Belmeguenai and Hansel, 2005), is also known to dephosphorylate EF2 kinase, which stimulates translation (Redpath and Proud, 1989).

Together with our recent report that many mRNAs encoding translation factors are present in the neuronal processes of Aplysia sensory neurons (Moccia et al., 2003), the dendritic localization of many transcripts encoding proteins involved in translational regulation suggests that local protein synthesis serves to increase the translational capacity of stimulated synapses, as described in the model shown in supplemental Figure 3 (available at www.jneurosci.org as supplemental material). Stimulus-induced local protein synthesis would increase the concentration of translation factors, and this would in turn promote the translation of other localized transcripts, both preexisting as well as newly transcribed mRNAs that are delivered to dendrites after transcription, such as BDNF or arc (Tongiorgi et al., 1997; Steward et al., 1998). In this manner, local translation would function to integrate the requirement for local translation with the requirement for transcription during long-lasting forms of plasticity. By providing a mechanism for newly transcribed mRNAs to be translated specifically at previously stimulated synapses, local synthesis of translation factors would function as an effective synaptic tag (Martin and Kosik, 2002).

The identification of a discrete population of dendritically localized mRNAs raises questions about the mechanisms whereby these specific mRNAs are targeted to dendrites and whereby their translation is regulated. A number of recent studies have highlighted a role for RNA binding proteins in RNA localization (e.g., Staufen, CPEB) and in translational regulation (FMRP) in neurons (for review, see Ule and Darnell, 2006; Wells 2006). Two RNA binding proteins that associate with dendritic mRNAs, Staufen and FMRP, are components of RNA granules (Villace et al., 2004). Our RNA-Staufen immunoprecipitation and in situ hybridization data suggests that some of the mRNAs we identified are present in Staufen-containing RNA granules. Specifically, we found that EF1 $\alpha$ and EF2 mRNAs associated with Staufen both when examined by coimmunoprecipitation of RNA with Staufen and by double-label Staufen-EGFP/fluorescent in situ hybridization experiments. In the latter experiments, not all Staufen-EGFP puncta colocalized with EF1 $\alpha$ or EF2 mRNA, suggesting the existence of multiple Staufen-containing RNA granules, each carrying distinct sets of mRNAs. The fact that Staufen did not bind importin $\beta 1$ mRNA suggests the existence of nonStaufen containing RNA granules. Interestingly, several of the mRNAs from our microarray data have been identified previously as mRNA targets of FMRP, including G-protein $\alpha$-inhibiting 2 (Gn $\alpha$ i2), NNAT (neuronatin), eIF5, RIP3 (Rhointeracting protein 3 ), and cytoplasmic dynein light chain (Brown et al., 2001; Miyashiro et al., 2003).

Our results add to previous studies aimed at identifying dendritically localized transcripts in mature vertebrate neurons (Miyashiro et al., 1994; Crino and Eberwine, 1996; Tian et al., 1999; Eberwine et al., 2001, 2002; Sung et al., 2004; Zhong et al., 2006). Surprisingly, there is little overlap between the various populations of mRNAs that have been reported to be dendritically localized. Although this underscores the importance of confirming mRNA localization by in situ hybridization, as we have done in this study, it also indicates that a potentially very large number of transcripts can localize to dendrites and suggests that the specific population of mRNAs that are present in dendrites is regulated by development and by activity. In this study, we describe a new method to reliably obtain pure dendritic preparations that can be used to characterize localized mRNAs at different developmental states and following distinct stimulation paradigms. Together with new bioinformatic tools and methods to acutely perturb gene expression, such as RNA interference, this methodology will permit elucidation of the complex and intricate ways in which local translation alters structure and function in neurons.

\section{References}

Atkins CM, Nozaki N, Shigeri Y, Soderling TR (2004) Cytoplasmic polyadenylation element binding protein-dependent protein synthesis is regulated by calcium/calmodulin-dependent protein kinase II. J Neurosci 24:5193-5201.

Belmeguenai A, Hansel C (2005) A role for protein phosphatases 1, 2A, and 2B in cerebellar long-term potentiation. J Neurosci 25:10768-10772.

Brown V, Jin P, Ceman S, Darnell JC, O'Donnell WT, Tenenbaum SA, Jin X, Feng Y, Wilkinson KD, Keene JD, Darnell RB, Warren ST (2001) Microarray identification of FMRP-associated brain mRNAs and altered mRNA translational profiles in fragile X syndrome. Cell 107:477-487.

Buettner VL, LeBon JM, Gao C, Riggs AD, Singer-Sam J (2000) Use of terminal transferase-dependent antisense RNA amplification to determine the transcription start site of the Snrpn gene in individual neurons. Nucleic Acids Res 28:E25.

Burgin KE, Waxham MN, Rickling S, Westgate SA, Mobley WC, Kelly PT (1990) In situ hybridization histochemistry of $\mathrm{Ca}^{2+} /$ calmodulin-dependent protein kinase in developing rat brain. J Neurosci 10:1788-1798.

Cans C, Passer BJ, Shalak V, Nancy-Portebois V, Crible V, Amzallag N, Allanic D, Tufino R, Argentini M, Moras D, Fiucci G, Goud B, Mirande M, Amson R, Telerman A (2003) Translationally controlled tumor protein acts as a guanine nucleotide dissociation inhibitor on the translation elongation factor eEF1A. Proc Natl Acad Sci USA 100:13892-13897.

Crino PB, Eberwine J (1996) Molecular characterization of the dendritic growth cone: regulated mRNA transport and local protein synthesis. Neuron 17:1173-1187.

Eberwine J, Miyashiro K, Kacharmina JE, Job C (2001) Local translation of classes of mRNAs that are targeted to neuronal dendrites. Proc Natl Acad Sci USA 98:7080-7085.

Eberwine J, Belt B, Kacharmina JE, Miyashiro K (2002) Analysis of subcellularly localized mRNAs using in situ hybridization, mRNA amplification, and expression profiling. Neurochem Res 27:1065-1077.

Garner CC, Matus A (1988) Selective localization of messenger RNA for cytoskeletal protein MAP2 in dendrites. Nature 336:674-677.

Giuditta A, Kaplan BB, van Minnen J, Alvarez J, Koenig E (2002) Axonal and presynaptic protein synthesis: new insights into the biology of the neuron. Trends Neurosci 25:400-404.

Giustetto M, Hegde AN, Si K, Casadio A, Inokuchi K, Pei W, Kandel ER, Schwartz JH (2003) Axonal transport of eukaryotic translation elongation factor 1alpha mRNA couples transcription in the nucleus to long-term facilitation at the synapse. Proc Natl Acad Sci USA 100:13680-13685.

Grooms SY, Noh K-M, Regis R, Bassell GJ, Bryan M, Carroll RC, Zukin RS (2006) Activity bidirectionally regulates AMPA receptor mRNA abundance in dendrites of hippocampal neurons. J Neurosci 26:8339-8351.

Guzowski JF, Setlow B, Wagner EK, McGaugh JL (2001) Experiencedependent gene expression in the rat hippocampus after spatial learning: a comparison of the immediate-early genes Arc, c-fos, and zif268. J Neurosci 21:5089-5098.

Hanz S, Perlson E, Willis D, Zheng JQ, Massarwa R, Huerta JJ, Koltzenburg M, Kohler M, van-Minnen J, Twiss JL, Fainzilber M (2003) Axoplasmic importins enable retrograde injury signaling in lesioned nerve. Neuron 40:1095-1104.

Huang F, Chotiner JK, Steward O (2005) The mRNA for elongation factor $1 \alpha$ is localized in dendrites and translated in response to treatments that induce long-term depression. J Neurosci 25:7199-7209.

Huynh JR, Munro TP, Smith-Litiere K, Lepesant JA, St. Johnston D (2004) The Drosophila hnRNPA/B homolog, Hrp48, is specifically required for a distinct step in osk mRNA localization. Dev Cell 6:625-635.

Jivotovskaya AV, Valasek L, Hinnebusch AG, Nielsen KH (2006) Eukaryotic 
translation initiation factor 3 (eIF3) and eIF2 can promote mRNA binding to 40S subunits independently of eIF4G in yeast. Mol Cell Biol 26:1355-1372.

Ju W, Morishita W, Tsui J, Gaietta G, Deerinck TJ, Adams SR, Garner CC, Tsien RY, Ellisman MH, Malenka RC (2004) Activity-dependent regulation of dendritic synthesis and trafficking of AMPA receptors. Nat Neurosci 7:244-253.

Kahvejian A, Svitkin YV, Sukarieh R, M'Boutchou MN, Sonenberg N (2005) Mammalian poly(A)-binding protein is a eukaryotic translation initiation factor, which acts via multiple mechanisms. Genes Dev 19:104-113.

Karsten S, Geschwind DH (2003) Gene expression analysis using cDNA microarrays. In: Current protocols in neuroscience (Crawley JN, Rogawski MA, Sibley DR, Skolnick P, Wray S, eds), Suppl 20, Sec 4, Unit 4.28. Hoboken, NJ: Wiley.

Kiebler MA, Hemraj I, Verkade P, Kohrmann M, Fortes P, Marion RM, Ortin J, Dotti CG (1999) The mammalian staufen protein localizes to the somatodendritic domain of cultured hippocampal neurons: implications for its involvement in mRNA transport. J Neurosci 19:288-297.

Klann E, Dever TE (2004) Biochemical mechanisms for translational regulation in synaptic plasticity. Nat Rev Neurosci 5:931-942.

Krichevsky AM, Kosik KS (2001) Neuronal RNA granules: a link between RNA localization and stimulation-dependent translation. Neuron 32:683-696.

Link W, Konietzko U, Kauselmann G, Krug M, Schwanke B, Frey U, Kuhl D (1995) Somatodendritic expression of an immediate early gene is regulated by synaptic activity. Proc Natl Acad Sci USA 92:5734-5738.

Litman P, Barg J, Ginzburg I (1994) Microtubules are involved in the localization of tau mRNA in primary neuronal cell cultures. Neuron 13:1463-1474.

Lyford GL, Yamagata K, Kaufmann WE, Barnes CA, Sanders LK, Copeland NG, Gilbert DJ, Jenkins NA, Lanahan AA, Worley PF (1995) Arc, a growth factor and activity-regulated gene, encodes a novel cytoskeletonassociated protein that is enriched in neuronal dendrites. Neuron 14:433-445.

Maiti T, Maitra U (1997) Characterization of translation initiation factor 5 (eIF5) from Saccharomyces cerevisiae. Functional homology with mammalian eIF5 and the effect of depletion of eIF5 on protein synthesis in vivo and in vitro. J Biol Chem 272:18333-18340.

Mallardo M, Deitinghoff A, Muller J, Goetze B, Macchi P, Peters C, Kiebler MA (2003) Isolation and characterization of Staufen-containing ribonucleoprotein particles from rat brain. Proc Natl Acad Sci USA 100:2100-2105.

Martin KC (2004) Local protein synthesis during axon guidance and synaptic plasticity. Curr Opin Neurobiol 14:305-310.

Martin KC, Kosik KS (2002) Synaptic tagging-who's it? Nat Rev Neurosci 3:813-820.

Martin KC, Zukin RS (2006) RNA trafficking and local protein synthesis in dendrites: an overview. J Neurosci 26:7131-7134.

Mathisen PMJJ, Kawczak JA, Tuohy VK (1999) Visinin-like protein (VILIP) is a neuron-specific calcium-dependent double-stranded RNA-binding protein. J Biol Chem 274:31571-31576.

Medrano S, Steward O (2001) Differential mRNA localization in astroglial cells in culture. J Comp Neurol 430:56-71.

Miyashiro K, Dichter M, Eberwine J (1994) On the nature and differential distribution of mRNAs in hippocampal neurites: implications for neuronal functioning. Proc Natl Acad Sci USA 91:10800-10804.

Miyashiro KY, Beckel-Mitchener A, Purk TP, Becker KG, Barret T, Liu L, Carbonetto S, Weiler IJ, Greenough WT, Eberwine J (2003) RNA cargoes associating with FMRP reveal deficits in cellular functioning in Fmr 1 null mice 37:417-431.

Moccia R, Chen D, Lyles V, Kapuya E, E Y, Kalachikov S, Spahn CM, Frank J, Kandel ER, Barad M, Martin KC (2003) An unbiased cDNA library prepared from isolated Aplysia sensory neuron processes is enriched for cytoskeletal and translational mRNAs. J Neurosci 23:9409-9417.

Monshausen M, Putz U, Rehbein M, Schweizer M, DesGroseillers L, Kuhl D, Richter D, Kindler S (2001) Two rat brain staufen isoforms differentially bind RNA. J Neurochem 76:155-165.

Norman ED, Thiels E, Barrionuevo G, Klann E (2000) Long-term depression in the hippocampus in vivo is associated with protein phosphatase-dependent alterations in extracellular signal-regulated kinase. J Neurochem 74:192-198.

Novoradovskaya N, Whitfield ML, Basehore LS, Novoradovsky A, Pesich R, Usary J, Karaca M, Wong WK, Aprelikova O, Fero M, Perou CM, Botstein
D, Braman J (2004) Universal reference RNA as a standard for microarray experiments. BMC Genomics 5:20.

Piper M, Holt C (2004) RNA translation in axons. Annu Rev Cell Dev Biol 20:505-523.

Puskas LG, Zvara A, Hackler Jr L, Micsik T, van Hummelen P (2002) RNA amplification results in reproducible microarray data with slight ratio bias. Biotechniques 32:1336, 1338-1340.

Redpath NT, Proud CG (1989) The tumour promoter okadaic acid inhibits reticulocyte-lysate protein synthesis by increasing the net phosphorylation of elongation factor 2. Biochem J 262:69-75.

Schuman EM, Dynes JL, Steward O (2006) Synaptic regulation of translation of dendritic mRNAs. J Neurosci 26:7143-7146.

Si K, Giustetto M, Etkin A, Hsu R, Janisiewicz AM, Miniaci MC, Kim JH, Zhu H, Kandel ER (2003) A neuronal isoform of CPEB regulates local protein synthesis and stabilizes synapse-specific long-term facilitation in Aplysia. Cell 115:893-904.

Steward O, Schuman EM (2001) Protein synthesis at synaptic sites on dendrites. Annu Rev Neurosci 24:299-325.

Steward O, Wallace CS, Lyford GL, Worley PF (1998) Synaptic activation causes the mRNA for the IEG Arc to localize selectively near activated postsynaptic sites on dendrites. Neuron 21:741-751.

Sung YJ, Weiler IJ, Greenough WT, Denman RB (2004) Selectively enriched mRNAs in rat synaptoneurosomes. Brain Res Mol Brain Res 126:81-87.

Tanaka TS, Jaradat SA, Lim MK, Kargul GJ, Wang X, Grahovac MJ, Pantano S, Sano Y, Piao Y, Nagaraja R, Doi H, Wood III WH, Becker KG, Ko MS (2000) Genome-wide expression profiling of mid-gestation placenta and embryo using a 15,000 mouse developmental cDNA microarray. Proc Natl Acad Sci USA 97:9127-9132.

Tang SJ, Meulemans D, Vazquez L, Colaco N, Schuman E (2001) A role for a rat homolog of staufen in the transport of RNA to neuronal dendrites. Neuron 32:463-475.

Tian QB, Nakayama K, Okano A, Suzuki T (1999) Identification of mRNAs localizing in the postsynaptic region. Brain Res Mol Brain Res 72:147-157.

Tiedge H, Brosius J (1996) Translational machinery in dendrites of hippocampal neurons in culture. J Neurosci 16:7171-7181.

Tiruchinapalli DM, Oleynikov Y, Kelic S, Shenoy SM, Hartley A, Stanton PK, Singer RH, Bassell GJ (2003) Activity-dependent trafficking and dynamic localization of zipcode binding protein 1 and $\beta$-actin mRNA in dendrites and spines of hippocampal neurons. J Neurosci 23:3251-3261.

Tongiorgi E, Righi M, Cattaneo A (1997) Activity-dependent dendritic targeting of BDNF and TrkB mRNAs in hippocampal neurons. J Neurosci 17:9492-9505.

Torre ER, Steward O (1992) Demonstration of local protein synthesis within dendrites using a new cell culture system that permits the isolation of living axons and dendrites from their cell bodies. J Neurosci 12:762-772.

Tsokas P, Grace EA, Chan P, Ma T, Sealfon SC, Iyengar R, Landau EM, Blitzer $\mathrm{RD}$ (2005) Local protein synthesis mediates a rapid increase in dendritic elongation factor $1 \mathrm{~A}$ after induction of late long-term potentiation. J Neurosci 25:5833-5843.

Ule J, Darnell RB (2006) RNA binding proteins and the regulation of neuronal synaptic plasticity. Curr Opin Neurobio 16:102-110.

Villace P, Marion RM, Ortin J (2004) The composition of Staufencontaining RNA granules indicates their role in the regulated transport and translation of messenger RNAs. Nucleic Acids Res 32:2411-2420.

Wang H, Tiedge H (2004) Translational control at the synapse. Neuroscientist 10:456-466.

Weiler IJ, Irwin SA, Klintsova AY, Spencer CM, Brazelton AD, Miyashiro K, Comery TA, Patel B, Eberwine J, Greenough WT (1997) Fragile X mental retardation protein is translated near synapses in response to neurotransmitter activation. Proc Natl Acad Sci USA 94:5395-5400.

Wells DG (2006) RNA-binding proteins: a lesson in repression. J Neurosci 26:7135-7138.

Winder DG, Sweatt JD (2001) Roles of serine/threonine phosphatases in hippocampal synaptic plasticity. Nat Rev Neurosci 2:461-474.

Yano T, Lopez de Quinto S, Matsui Y, Shevchenko A, Shevchenko A, Ephrussi A (2004) Hrp48, a Drosophila hnRNPA/B homolog, binds and regulates translation of oskar mRNA. Dev Cell 6:637-648.

Zhong J, Zhang T, Bloch LM (2006) Dendritic mRNAs encode diversified functionalities in hippocampal pyramidal neurons. BMC Neurosci 7:17. 